Bangladesh J. Zool. 41(1): 1-11, 2013

\title{
EFFECT OF FREEZING PERIOD ON THE MICROBIAL AND NUTRIENT QUALITY OF POOL BARB, PUNTIUS SOPHORE FROM DHAKA CITY RETAIL MARKET, BANGLADESH
}

Md. Ghulam Mustafa*, Tamanna Yasmin, Saima Sharif Nilla, Md. Mahmudur Rahman Khan and Md. Anisur Rahman Khan ${ }^{1}$

Department of Fisheries, University of Dhaka, Dhaka-1000, Bangladesh.

\begin{abstract}
The microbiological and nutrient quality of pool barb (Jatpunti), Puntius sophore collected from three local markets - Ananda bazaar, New Market and Polashi bazaar of Dhaka, Bangladesh were assessed. The investigation confirmed more or less higher microbial load in Ananda bazaar samples than the others. The microbial quality varied with market sources as total bacterial counts (TBC), total coliform counts (TCC) and faecal coliform counts (FCC) occurred in all storage period and that crossed the acceptable limit. All studied parameters except E. coli were significantly different at 7 days and 30 days of storage period and a significant difference $(\mathrm{p}<0.05)$ was found in case of $E$. coli for all storage period where every 30 days storage showed one log reduction of bacterial count from every initial stage. The Salmonella shigella (SS) and Vibrio spp. were identified in all samples of studied local markets. An inverse relation was found between moisture and protein, moisture and fat, whereas the moisture content was increased after 30 days of freezing storage. This study concludes that the quality of $P$. sophore (Jatpunti) available in the studied three local markets of Dhaka city were neither satisfactory level nor to the standard for normal consumption.
\end{abstract}

Key words: Freezing period, Microbial quality, Puntius sophore, Retail market, Dhaka, Bangladesh

\section{INTRODUCTION}

Small Indigenous Species (SIS) of fish have high nutritional value in terms of proteins and vitamins that are not commonly available in other foods. Besides, the SIS are valuable source of micro and macro nutrients and play an important role in providing important nutrients to the people of Bangladesh. Among the SIS of fish, pool barb, Puntius sophore, locally known as jatpunti is a demandable and delicious fish to the Bangladeshi people.

Food safety refers to the potential hazards associated with food that can cause ill-health to human (Henson 2003). It concerns with animal protein derived from marketed fish, fishery products, meats and meat products that creates a high risk commodity regarding to microbial contaminations, adulterants and natural toxicity (Nilla et al. 2012a). Besides, bacteriological

*Corresponding author: E-mail: mgmustafabd@yahoo.com 1Department of Microbiology, University of Dhaka, Dhaka-1000, Bangladesh. 
quality is directly related to the spoilage of fish and becomes the cause of outbreak of food poisoning (Nilla et al. 2012b). Microbial hazards that are ingested in fish body at the post harvest period cause fish spoilage.

During the post harvest period, fishes continue to deteriorate due to improper handling and further processing can never bring back its freshness. Low quality frozen processing related with improper and poor hygienic condition (Nilla et al. 2012b), consequently contaminate the frozen fish with different types of bacteria spoiling the fish that may be responsible for cholera and other food borne diseases (Mobin et al. 2001).

Today people are turning to fish as a healthy alternative to red meat. The low fat content of many fish species and the effects of the polyunsaturated fatty acids on coronary heart disease found in fatty fish species are extremely important aspects for health conscious people (Huss 1994) and other minerals take part in some metabolic processes. But unfortunately fishes are contaminated during transportation to landing center and wholesale market, and may infect people associated in handling. When the consumers purchase these fish, the fish with high bacterial load are definitely transferred to person who carries them out (Das et al. 2007). It has been suggested repeatedly that the bacterial flora in fish might reflect the hygienic condition of market and potential indicator of contamination (Rashid et al. 2002). So to increase the marketed fish quality assurance in accordance with microbial occurrence assessment is deemed necessary.

This study was aimed to evaluate the microbial quality and quantity as well

as nutritional quality in locally available pool barb with a view to provide imminent approaches for marketed food safety of fish products.

\section{MATERIAL AND METHODS}

Sample collection and identification: Fresh jatpunti (Puntius sophore) fish samples were collected from three different local retail markets - Ananda bazaar, New Market and Polashi bazaar of Dhaka city between January to July 2011. The fish samples were collected by special sterile Ziploc bags to avoid further contamination and transported in an insulated box (ICMSF 1998) to the laboratory. Fish identification was done according to Rahman (2005) and Shafi and Quddus (2004).

Sample preparation: The samples were processed and 25 grams were used within 2 hours of collection. The samples were taken following the method of APHA (1998). Each sample was separately homogenized with $9 \mathrm{ml}$ of sterile normal saline solution and was prepared using one $\mathrm{ml}$ homogenized samples to 
$9 \mathrm{ml}$ of sterile normal saline to make it $0.1 \mathrm{ml}$ dilution of the treated samples in the pour plate.

Microbial analysis: Spread plate method was used to enumerate total bacterial count (TBC) using dehydrated nutrient agar (NA) medium and serial diluted samples were pour-plated on MacConkey and modified fecal coliform (mFC) agar for total coliform count (TCC) and fecal coliform count (FCC), respectively (BAM 2005). The colonies were incubated for $24 \mathrm{~h}$ at $35-37^{\circ} \mathrm{C}$ for TBC and at $44.5^{\circ} \mathrm{C}$ for $24 \mathrm{~h}$ for TCC and FCC. Further confirmation was done by growing cultures in eosin methylene blue (EMB) agar and calculated as colony forming unit per gram (cfu/g). A loopful of growth from the broth was streaked on Salmonella-Shigella agar (SSA), incubated for $48 \mathrm{~h}$ at $35-37^{\circ} \mathrm{C}$. Xylose Lysine Deoxycholate (XLD) agar was also used for the selective isolation of Shigella and Salmonella spp. Diluted homogenates were pour-plated on thiosulphate citrate bile sucrose (TCBS) agar to enumerate Vibrio spp. All cultured pathogens were identified by biochemical tests

Biochemical tests: Biochemical tests were done according to the Manual for General Bacteriology of the American Society of Microbiology (ASM 1981). Oxidase test, catalase test, carbohydrate fermentation utilization test, Kligler's iron agar (KIA) test, indole production test, methyl red (MR) test, VogesProskauer (VP) test, citrate utilization test, nitrate reduction test, motility indole urea (MIU) tests, and salt tolerance $(3 \%, 5 \%, 10 \%$ and $15 \% \mathrm{NaCl})$ test were done to identify the bacteria (Cappuccino and Sherman 1990).

Proximate composition analysis: Proximate analysis such as moisture, protein, lipid and ash were carried out following the methods of AOAC (1984).

Statistical analysis: Statistical analysis was performed with the SPSS software package (verson11.5, SAS Institute Inc, Cary, USA) following Tukey's HSD post hoc for the multiple comparisons.

\section{RESULTS AND DISCUSSION}

Table 1 shows the mean ( \pm SEM) microbial density (TBC, TCC, FCC, EC, SS and Vibrio spp.) at four freezing period (0, 1, 7, 30 days) of pool barb collected from three different local markets of Dhaka city under normal condition and different freezing periods. The results confirm that microbial load was more or less higher in Ananda bazaar samples than the others.

Total bacterial count (TBC): The highest TBC load $\left(7.7 \pm 0.07 \times 10^{7}\right)$ was found in normal condition ( 0 day) of Ananda bazaar sample and the lowest load $\left(6.3 \pm 0.18 \times 10^{6}\right)$ was after 30 days storage in sample from Polashi bazaar (Table 1). There was no significant difference $(p<0.05)$ found in TBC of the samples 


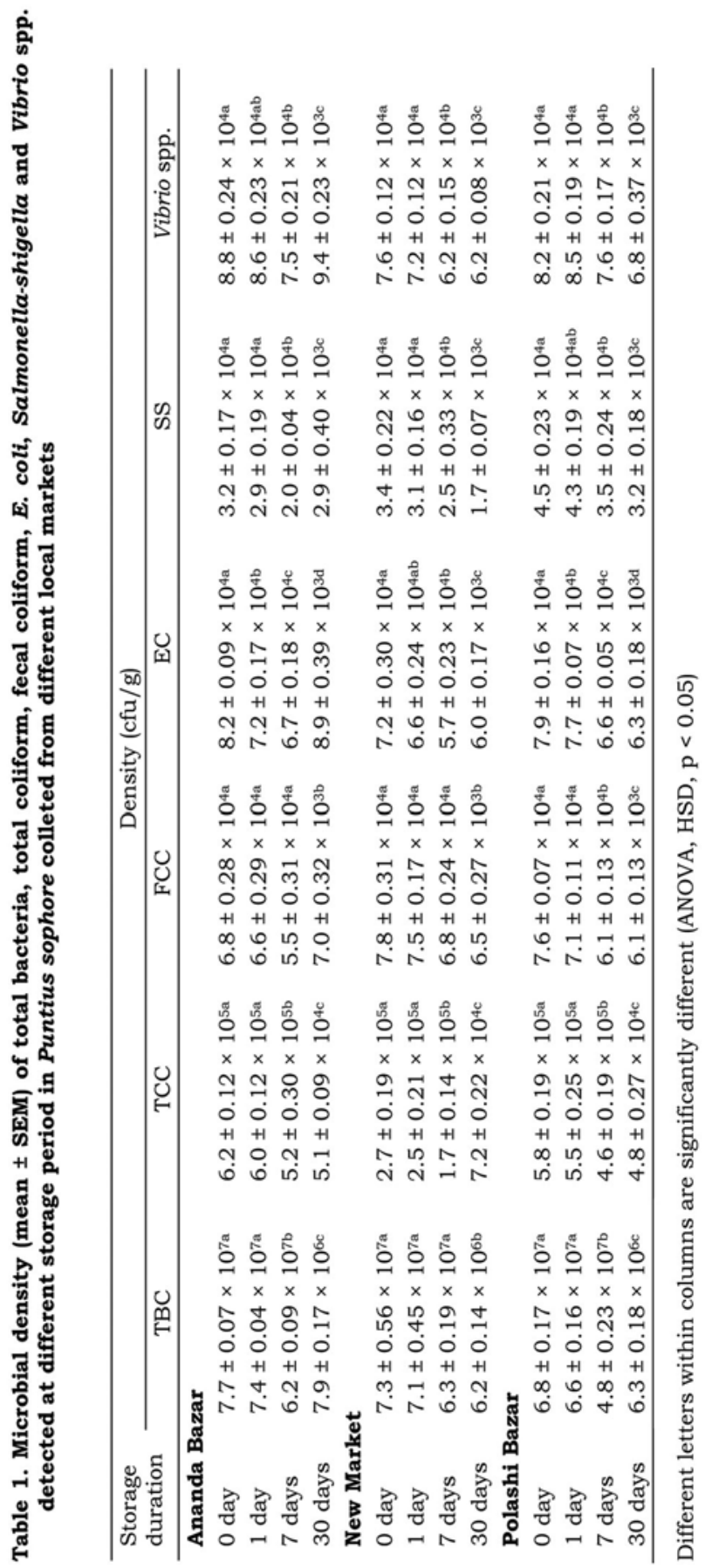


between normal condition and day 1 storage for all local markets. But after 7 days and 30 days freezing period, the TBC were significantly different where 30 days period showed 1 log reduction of bacterial count from every initial stage.

Total coliform count (TCC): The highest TCC $\left(6.2 \pm 0.12 \times 10^{5} \mathrm{cfu} / \mathrm{g}\right)$ was found in Ananda bazaar sample at day 0 and the lowest density was $4.8 \pm 0.27 \times$ $10^{4} \mathrm{cfu} / \mathrm{g}$ in Polashi bazaar sample after 30 days storage period as shown in Table 1. There was no significant difference $(\mathrm{p}<0.05)$ found in TCC of the samples between day 0 and day 1 storage. But the TCC were significantly different in 7 days and 30 days freezing period, where 30 days period showed 1 log reduction of bacterial count from every initial stage, for all local markets.

Fecal coliform count (FCC) and E. coli (EC): The highest FCC and EC were found at normal condition (day 0) as $7.8 \pm 0.31 \times 10^{4} \mathrm{cfu} / \mathrm{g}$ in New Market and $8.2 \pm 0.09 \times 10^{4} \mathrm{cfu} / \mathrm{g}$ in Ananda bazaar samples, respectively whereas the lowest were found after 30 days storage as $6.1 \pm 0.13 \times 10^{3} \mathrm{cfu} / \mathrm{g}$ in Polashi bazaar sample and $6.0 \pm 0.17 \times 10^{3} \mathrm{cfu} / \mathrm{g}$ in New Market sample, respectively (Table 1). Like TBC, there was no significant difference $(\mathrm{p}<0.05)$ found for FCC between day 0 and day 1 storage for all markets samples. They were significantly different in 7 days and 30 days storage period, but EC showed a significant difference $(p<0.05)$ for all storage period where every 30 days storage showed 1 log reduction of bacterial count from every initial stage (Table 1).

Salmonella-Shigella (SS): The highest intensity $\left(4.5 \pm 0.23 \times 10^{4} \mathrm{cfu} / \mathrm{g}\right)$ and the lowest level $\left(1.7 \pm 0.07 \times 10^{3} \mathrm{cfu} / \mathrm{g}\right)$ of Salmonella-Shigella (SS) were found at day 0 in Polashi bazaar and at 30 days storage in New Market sample, respectively (Table 1$)$. A significant difference $(p<0.05)$ was found among the SS abundance in all but day 0 storage period for the three market sources. The SS was identified in all samples from the three studied local markets.

Vibrio spp.: The presence of Vibrio spp. can be a cause of infection to the consumers. In the present study, Vibrio spp. was found in all samples. Table 1 shows that the highest load was found in Ananda bazaar sample $(8.8 \pm 0.24 \times$ $\left.10^{4} \mathrm{cfu} / \mathrm{g}\right)$ in normal condition (0 day) and the lowest density $\left(6.2 \pm 0.08 \times 10^{3}\right.$ $\mathrm{cfu} / \mathrm{g})$ in New Market sample at 30 days storage period. A significant difference $(\mathrm{p}<0.05)$ was found among the Vibrio spp. abundance in all but 0 day and 1 day storage period for the three market sources.

Nutrient composition: The lowest moisture percentage was $75.24 \pm 4.92$ in New Market fish sample at day 0 and the highest was $80.12 \pm 5.14$ after 30 days storage in Ananda bazaar sample (Table 2). The highest protein and lipid contents were found in New Market samples $(18.15 \pm 2.88$ and $5.88 \pm 0.92)$ at day 0, the lowest were $15.88 \pm 2.28$ and $2.68 \pm 0.32$ in Ananda bazaar sample in 30 days, respectively. Besides, the highest ash (1.27 \pm 0.55$)$ was found at 30 
days storage and the lowest $0.54 \pm 0.22$ at 0 day storage period in Ananda bazaar and Polashi bazaar sample, respectively. A significant difference $(\mathrm{p}<$ 0.05) was found between the storage duration for all nutrient contents of the three studied markets. An inverse relation was found between moisture and protein, moisture and fat in this study, where the moisture content increased after 30 days freezing storage but protein and lipid contents were decreased with time.

In this study, the whole fish was considered for microbial analysis, it might be the reason for higher TBC occurrence in all storage period and crossing the acceptable limit $\left(10^{5} \mathrm{cfu} / \mathrm{g}\right)$ given by International Commission on Microbiological Specifications for Foods (ICMSF 1986). The present findings are supported by some previous works of different scientists who worked on punti and small fish. Nilla et al. (2012b) found TBC ranged between $1.8 \pm 0.25 \times 10^{4}$ to $6.5 \pm 0.75 \times 10^{6} \mathrm{cfu} / \mathrm{g}$ in mola fish (Amblypharyngodon mola) from local markets of Dhaka metropolis where the whole fish was considered for bacterial quality analysis. Begum et al. (2010) found TVBC (total viable bacterial counts) $3.3 \times$ $10^{5}$ to $1.9 \times 10^{8} \mathrm{cfu} / \mathrm{g}$ in sarpunti (Puntius sarana) collected from local markets. On the contrary, Zahid et al. (2011) estimated SPC (standard plate count) $3.95 \times$ $10^{4} \mathrm{cfu} / \mathrm{g}$ in sarpunti ( $P$. sarana) from local market at normal condition which was below the acceptable limit.

Table 2. Nutritional composition (mean \pm SEM) of Puntius sophore samples from different local markets at different freezing duration

\begin{tabular}{llllll}
\hline Source & Freezing duration & Moisture (\%) & Protein (\%) & Lipid (\%) & Ash (\%) \\
\hline Ananda Bazar & 0 day & $75.58 \pm 0.86^{\mathrm{a}}$ & $17.86 \pm 0.54^{\mathrm{a}}$ & $5.59 \pm 0.88^{\mathrm{a}}$ & $0.88 \pm 0.37^{\mathrm{b}}$ \\
& 30 days & $80.12 \pm 1.14^{\mathrm{b}}$ & $15.88 \pm 0.28^{\mathrm{c}}$ & $2.68 \pm 0.32^{\mathrm{b}}$ & $1.27 \pm 0.55^{\mathrm{a}}$ \\
New Market & 0 day & $75.24 \pm 0.92^{\mathrm{a}}$ & $18.15 \pm 0.88^{\mathrm{a}}$ & $5.88 \pm 0.92^{\mathrm{a}}$ & $0.71 \pm 0.34^{\mathrm{b}}$ \\
& 30 days & $79.60 \pm 1.06^{\mathrm{b}}$ & $16.39 \pm 0.17^{\mathrm{b}}$ & $2.79 \pm 0.48^{\mathrm{b}}$ & $1.17 \pm 0.48^{\mathrm{a}}$ \\
\multirow{3}{*}{ Polashi Bazar } & 0 day & $75.48 \pm 0.96^{\mathrm{a}}$ & $18.07 \pm 0.92^{\mathrm{a}}$ & $5.65 \pm 0.95^{\mathrm{a}}$ & $0.54 \pm 0.22^{\mathrm{c}}$ \\
& 30 days & $79.32 \pm 0.84^{\mathrm{b}}$ & $16.58 \pm 0.45^{\mathrm{b}}$ & $2.96 \pm 0.55^{\mathrm{b}}$ & $1.09 \pm 0.45^{\mathrm{a}}$ \\
\hline
\end{tabular}

Different letters within columns show significant difference between storage duration (ANOVA, HSD, $\mathrm{p}<0.05)$

The bacteriological quality of Ananda bazaar shrimp was found to be comparatively poor than other local markets; this might be because of the contamination by harmful microorganisms from the source of water, poor hygiene and sanitation condition of the market premises (Nilla et al. 2012a, b; Hatha et al. 2003). The contamination might have also occurred from catching vessels (Wahab et al. 2003), poor and untrained handling of fish in unhygienic environment by fish dwellers in various phases during transportation from catch point to markets. In addition, most of the microbes which had limited growth for 
a short period, can multiply within short time when favorable condition comes back (Leita ${ }^{\circ} \mathrm{O}$ and Rios 2000).

In case of total coliform count (TCC), high quantity of bacteria were observed in all samples exceeding the suggested limit as $10^{2} \mathrm{cfu} / \mathrm{g}$ by ICMSF (ICMSF 1986). Nilla et al. (2012b) found TCC $2.4 \pm 0.30 \times 10^{3}$ to $8.0 \pm 0.55 \times 10^{4} \mathrm{cfu} / \mathrm{g}$ in A. mola from Dhaka metropolis local markets whereas Begum et al. (2010) found highest TC $>240 \mathrm{mpn} / \mathrm{g}$ in local marketed $B$. sarana. On the contrary, Zahid et al. (2011) did not found TCC in normal $P$. sarana from local markets.

The handling processes, preservation ways and selling in the markets including holding temperature might be the reason for the presence of total coliform in the studied samples. Nilla et al. (2012b) reported sewage contagion in the market as a contamination source of fish. Moreover, the water use for washing or icing may act as contamination sources for fish (Boyd 1990).

Center for Disease Control and Prevention (CDC 2010) proved that fecal coliform count $(\mathrm{FCC})$ is as more accurate indication of animal or human waste than the total coliform count (TCC) because the FCC origins are more specific than the origins of the TCC.

Nilla et al. $(2012 \mathrm{~b})$ found that the lowest FCC $\left(7.6 \pm 0.15 \times 10^{2}\right)$ and EC $(1.4$ $\left.\pm 0.15 \times 10^{3} \mathrm{cfu} / \mathrm{g}\right)$, respectively and the highest count for both was $4.8 \pm 0.45 \times$ $10^{4} \mathrm{cfu} / \mathrm{g}$ in A. mola from local markets of Dhaka metropolis and Begum et al. (2010) found FCC (0.4 to $110 \mathrm{mpn} / \mathrm{g}$ ) in local marketed B. sarana. But Zahid et al. (2011) did not record any FCC in normal P. sarana from local market. So, the result of present study indicates that the water and/or market premises were somehow contaminated. Since the bacteria were found in high concentration, the water could be linked directly or indirectly to contamination by human sewage.

As the results in this study for safety fish samples, were found exceeding the limit $\left(1.0 \times 10^{2} \mathrm{cfu} / \mathrm{g}\right)$ in fish and fish food (ICMSF 1986), further identification was carried out to investigate the presence of other harmful and pathogenic microorganisms such as Salmonella spp., Shigella spp. and Vibrio spp.

As the mola fish of present study directly come from the sources of Dhaka city, the fish might contain SS isolates (Reilly et al. 1992). Nilla et al. (2012b) found SS in $75 \%$ of fresh A. mola samples from Dhaka metropolis local markets that ranged from $1.0 \pm 0.10 \times 10^{2}$ to $5.3 \pm 0.30 \times 10^{3} \mathrm{cfu} / \mathrm{g}$ whereas Begum et al. (2010) found SS in 3 out of 4 sources for local marketed $P$. sarana samples. But the SS was not detected by Zahid et al. (2011) in normal P. sarana from local market. WHO reported that in India $1.41 \times 10^{2} \mathrm{cfu} / \mathrm{g}$ as the estimated incidence of food-borne Salmonella occurred in fish and seafood products (Henson 2003). 
In case of Vibrio spp., Nilla et al. (2012b) found in $83 \%$ of fresh A. mola samples from local markets of Dhaka metropolis that ranged from $1.3 \pm 0.10 \times$ $10^{2}$ to $3.5 \pm 0.25 \times 10^{3} \mathrm{cfu} / \mathrm{g}$ Vibrio spp., whereas Begum et al. (2010) found Vibrio spp. in all (4 out of 4) sources for local marketed B. sarana. On the contrary, Vibrio spp. was not detected in normal local marketed $P$. sarana by Zahid et al. (2011).

It was very remarkable to find Vibrio spp. in fish samples after 30 days storage because Vibrio normally cannot survive in the frozen condition due to the absence of moisture (Jay 1996). The probable reasons for survival of Vibrio spp. after 30 days storage were the inadequate freezing condition and the presence of moisture during freezing. Besides, Vibrio spp. present mainly in intestine of fish and as the whole fish was considered for microbial analysis, so the density was high (Nilla et al. 2012a). This result revealed that microbial quality of local markets was not good due to presence of Vibrio spp. in all samples.

The environment rather than poor standards of hygiene and sanitation is mainly responsible for the instigation of the SS in fish and fish products. Sometimes external contamination is accountable for the occurrence of bacteria in fish (Huss 1994). Moreover, diarrheal stools of infected persons are highly laden of FC. The diarrheal infected food handlers forget to wash hands with soap after using the bathroom and start to operate fishing gears or work in the markets may also act as contaminate source of food (CDC 2010).

The body composition of fish seems to depend on age, sex, seasons and diet (Graves 1970) and varied from species to species and even within the same species from one individual to another (Stansby 1962). The present study was more or less in agreement with the general rule formulated by Standby (1962) and the findings of Nurullah et al. (2003). Mustafa et al. (2012) recorded moisture, protein, lipid and ash in percentage to be $71.39 \pm 0.61,16.73 \pm 0.92$, $9.0 \pm 1.09$ and $2.02 \pm 0.24$, respectively in sarpunti $(P$. sarana). Siddique et al. (2011) estimated moisture, protein and lipid in $P$. sophore at 0 day as 75.4 , 17.89 and $5.8 \%$, respectively and $78.12,16.20$ and $3.75 \%$, respectively at 20 days freezing period. Nurullah et al. (2003) found that the average moisture content was increased $72.97 \%$ (in fresh punti) to $75.77 \%$ in 8 days freezing condition, whereas protein, lipid and ash reduced from 18.95, 6.27 and $0.98 \%$ in fresh condition to $16.56,4.21$ and $1.93 \%$ (8 days freezing condition), respectively. Similar inverse relation between fat and moisture content was also recorded by Hossain et al. (1999). The present findings are almost supported by these results. Deviation may occur due to natural feeding habits and availability 
of feed, fasting duration during spawning and migration etc. (Viswanathan and Mathew 2000).

The abundance of high bacterial load in the fish samples from different markets indicates a possibility of future outbreak of pathogenic diseases through ingestion of contaminated fish including chances of cross contamination via kitchen utensils or by handling. The presence of high bacterial load in the fish samples may indicate fecally contaminated water sources and also rough handling and poor hygienic practices by fisherman and market dwellers. So the main reasons for infecting the local marketed punti might be rough handling and sorting or lack of sanitation. To overcome this situation, it is necessary to follow the code of practice concerning handling, icing and hygiene measures. Regular monitoring of local fish markets should be done and consumer's awareness on food safety should be increased through awareness building program about microbial and chemical status of the fishes of our country to secure public health as well as same considerable economic and social costs.

Acknowledgements: The authors greatly acknowledge the support and facilities provided by Department of Fisheries and Department of Microbiology, University of Dhaka.

\section{LITERATURE CITED}

AOAC (ASSOCIATION OF OFFICIAL ANALYTICAL CHEMISTS). 1984. Official methods of Analysis. Association of Official Analytical Chemists. $13^{\text {th }}$ edition, Washington DC.

ASM (AMERICAN SOCIETY OF MICROBIOLOGY). 1981. Manual for General Bacteriology. Website: http://ourfood.com/General bacteriology.html. Accessed on 11-01-2011.

BEGUM, M., AHMED, A.T.A., DAS, M. and PARVEEN, S. 2010. A comparative microbiological assessment of five types of selected fishes collected from two different market. Advances in Biol. Res. 4(5): 259-265.

BOYD, C.E. 1990. Water Quality in Ponds for Aquaculture. Birmingham Publishing Co., Alabama, USA. 480 pp.

CAPPUCCINO, J.G. and SHERMAN, N. 1990. Microbiology: A Laboratory Manual. 4th Edition. McMillan Publications, London, 137-183pp.

CDC (CENTER FOR DISEASE CONTROL AND PREVENTION), FAQ. 2010. Escherichia coli. Website: http://www.cdc.gov/ncidod/dbmd/diseaseinfo/escherichiacoli_g.html. Accessed on 21-042011.

DAS, M., AHMED, K.M. and PARVEEN, S., 2007. Microbiological analysis of some raw fish samples. Bangladesh J. Microbiol. 24(1): 67-69.

HATHA, M.A.A., MAQBOOL, T.K. and KUMAR, S. 2003. Microbial quality of shrimp products of export trade produced from aquacultured shrimp. Int. J. Food Microbiol. 5(2): 82, 213-221. 
HENSON, S. 2003. The Economics of Food Safety in Developing Countries. ESA working paper 3-19. FAO, Rome, Italy.

HOSSAIN, M.A., AFSANA, K. and SHAH, K.M.A. 1999. Nutritional value of some small indigenous fish species (SIS) of Bangladesh. Bagladesh J. Fish. Res. 3(1): 77-85.

HUSS, H.H. 1994. Assurance of Seafood Quality. FAO Fisheries Technical Paper 334. Food and Agriculture Organization, Rome. 94, 97, 169 pp.

ICMSF. 1986. Microorganisms in Foods. In: Application of the Hazard Analysis Critical Control Point (HACCP) System to Ensure Microbiological Safety and Quality. Blackwell Scientific Publications. 42pp.

JAY, J.M. 1996. Modern Food Microbiology. 4th edition. Maryland: Aspen Publishers Inc. 583-585pp.

LEITA O, M.F.F. and RIOS, D.P.A. 2000. Microbiological and Chemical Changes in Freshwater Prawn Stored Under Refrigeration. Braz. J. Microbiol. 31: 178-183.

MOBIN, S.M.A., CHOWDHURY, M.B.R., ISLAM, M.S. and UDDIN, M.N. 2001. Status of bacterial flora in the intestine of two freshwater fish. Bangladesh J. Life Sci. 13(1\&2): 149-155.

MUSTAFA, M.G., BEGUM, S.R., KHALEQUE, M.A., JANNAT, M. and AHSAN, D.A. 2012. Nutritional Qualities of Hilsha and Sarpunti in Different Salt Curing Methods. Dhaka Univ. J. Biol. Sci. 21(1): 97-104.

NILLA, S.S., MUSTAFA, M.G., AHSAN, D.A., KHAN, M.M.R. and KHAN, M.A.R. 2012a. Bacterial abundance in Indian White Shrimp, Penaeus indicus collected from two different market conditions of Dhaka city. Dhaka Univ. J. Biol. Sci. 21(1): 29-38.

NILLA, S.S., KHAN, M.A.R., KHAN, M.M.R., AHSAN, D.A. and MUSTAFA, M.G. 2012b. Bacteriological quality of marketed mola fish, Amblypharyngodon mola from Dhaka metropolis. Bangladesh $J$. Zool. 40(1): 77-88.

NURULlAH, M., KAMAL, M., WAHAB, M.A., ISLAM, M.N., AHASAN, C.T., and THILSTED, S.H. 2003. Nutritional quality of some small indigenous fish species of Bangladesh. In: Small Indigenous Species of Fish in Bangladesh (eds. Wahab, M.A., Thilsted, S.H. and Hoq, M.E.), Technical Proc. of BAU-ENRECA/DANIDA Workshop on Potentials of Small Indigenous Species of Fish (SIS) in Aquaculture \& Rice-field Stocking for Improved Food \& Nutrition Security in Bangladesh. 30-31 October 2002, BAU, Mymensingh, Bangladesh. pp 151-158.

RAHMAN A.K.A. 2005. Freshwater Fishes of Bangladesh. 2nd ed. Zool. Soc. Bangladesh, Dhaka, Bangladesh, xviii+ 152-153pp.

RASHID, H., RABBY, A.F.M., ASADUZZAMAN, S.M., DEBNATH, G.C., KHAN, M.A.R. and CHOUDHURY, N. 2002. Bacteriogical analysis of Catla fish (Catla catla) in marketing conditions. Bangladesh J. Microbiol. 19(1\&2): 99-100.

REILLY, P.J.A., TWIDDY, D.R. and FUCHS, R.S. 1992. Review of the Occurrence of Salmonella in Cultured Tropical Shrimp. FAO Fish. Circ. No. 851. FAO, Rome, Italy.

SHAFI, M. and QUDDUS, M.M.A. 2004. Bangladesh Matsho Shampad (Fisheries of Bangladesh). 2nd edition. Kabir Publications, Dhaka. 121-122pp.

SIDDIQUE, M.N., HASAN, M.J., RAHMAN, M.Z., ISLAM, M.R., BODURUZAMAN, M., REZA, M.F. and RAY, S. 2011. Effect of freezing time on nutritional value of Jatpunti (Puntius sophore), Sarpunti (P. sarana) and Thaisanpunti (P. gonionotus). Bangladesh Res. Pub. J. 5(4): 387-392.

STANSBY, M.E. 1962. Proximate Composition of Fish. In: Fish in Nutrition (eds. Heen and R. Kreuzer). Fishing News (Books) Ltd., UK. 
VISWANATHAN, P.G.N. and MATHEW, S. 2000. Biochemical composition of fish and shellfish. Central Institute of Fisheries Technology, Cochin. CIFT Technology Advisory Series. pp. 4-7.

WAHAB, M.A., BERGHEIM, A. and BRAATEN, B. 2003. Water Quality and Partial Mass Budget in Extensive Shrimp Ponds in Bangladesh. Science Direct (Internet ed). 218: 413-423pp.

ZAHID, M.A., AKHTER, N., JAHAN, N., AZAM, M.N.K. and NAHAR, N. 2011. A comparative study on quality assessment of traditional and conventional dried fishes of Chapila (Gudusia chapra) and Punti (Puntius sarana). J. Innov. Dev. Strategy. 5(3): 47-56.

(Manuscript received on 30 September 2012; revised on 20 May 2013) 